Article

\title{
Sustainability Assessment of Modern High-Rise Timber Buildings
}

\author{
Laura Tupenaite $^{1, *}$, Viktorija Zilenaite ${ }^{1}$, Loreta Kanapeckiene ${ }^{1}$, Tomas Gecys ${ }^{2}$ and Ineta Geipele ${ }^{3}$ \\ 1 Department of Construction Management and Real Estate, Faculty of Civil Engineering, Vilnius Gediminas \\ Technical University, Sauletekio al. 11, LT-10223 Vilnius, Lithuania; viktorija.zilenaite@gmail.com (V.Z.); \\ loreta.kanapeckiene@vilniustech.lt (L.K.) \\ 2 Department of Steel and Composite Structures, Faculty of Civil Engineering, Vilnius Gediminas Technical \\ University, Sauletekio al. 11, LT-10223 Vilnius, Lithuania; tomas.gecys@vilniustech.lt \\ 3 Institute of the Civil Engineering and Real Estate Economics, Faculty of Engineering Economics and \\ Management, Riga Technical University, Kalnciema Str. 6-211, LV 1048 Riga, Latvia; Ineta.Geipele@rtu.lv \\ * Correspondence: laura.tupenaite@vilniustech.lt; Tel.: +370-65280529
}

Citation: Tupenaite, L.; Zilenaite, V.; Kanapeckiene, L.; Gecys, T.; Geipele, I. Sustainability Assessment of Modern High-Rise Timber Buildings. Sustainability 2021, 13, 8719. https:// doi.org/10.3390/su13168719

Academic Editor: Manuel Duarte Pinheiro

Received: 30 June 2021

Accepted: 3 August 2021

Published: 4 August 2021

Publisher's Note: MDPI stays neutral with regard to jurisdictional claims in published maps and institutional affiliations.

Copyright: (C) 2021 by the authors. Licensee MDPI, Basel, Switzerland. This article is an open access article distributed under the terms and conditions of the Creative Commons Attribution (CC BY) license (https:// creativecommons.org/licenses/by/ $4.0 /)$.

\begin{abstract}
As woodworking and construction technologies improve, the construction of multi-storey timber buildings is gaining popularity worldwide. There is a need to look at the design of existing buildings and assess their sustainability. The aim of the present study is to assess the sustainability of modern high-rise timber buildings using multi-criteria assessment methods. The paper presents a hierarchical system of sustainability indicators and an assessment framework, developed by the authors. Based on this framework, the tallest timber buildings in different countries, i.e., Mjøstårnet in Norway, Brock Commons in Canada, Treet in Norway, Forte in Australia, Strandparken in Sweden and Stadthaus in UK, were compared across the three dimensions of sustainability (environmental, economic/technological, and social). Research has revealed that none of the buildings is leading in all dimensions of sustainability. However, each building is unique and has its own strengths. Overall multi-criteria assessment of the buildings revealed that the Brock Commons building in Canada has received the highest rank in all dimensions of sustainability. The paper contributes to the theory and practice of sustainability assessment and extends the knowledge about high-rise timber buildings. The proposed sustainability assessment framework can be used by both academics and practitioners for assessment of high-rise timber buildings.
\end{abstract}

Keywords: high-rise timber buildings; sustainability; indicators; multi-criteria assessment; AHP; SAW

\section{Introduction}

The concept of sustainable development, which was formulated in the 1990s, is becoming increasingly relevant today. "Humanity has the ability to make development sustainable to ensure that it meets the needs of the present without compromising the ability of future generations to meet their own needs" [1]. It is also important to reconcile three key aspects in order to achieve sustainable development: environmental, economic and social. Sustainable development is particularly relevant in the construction sector.

The 2020 Global Status Report for Buildings and Construction revealed that global building energy consumption remained steady year-on-year; however, energy-related $\mathrm{CO}_{2}$ emissions increased to $9.95 \mathrm{GtCO}_{2}$ in 2019 [2]. When adding emissions from the building construction industry on top of operational emissions, the sector accounted for $38 \%$ of total global energy-related $\mathrm{CO}_{2}$ emissions [2]. These figures show that the construction industry has a significant negative impact on the environment. Furthermore, the construction sector is distinguished from other industrial sectors by the long-term nature of its output, i.e., a building can take a year or more to construct and, depending on the complexity of the project, can last for more than 50 years. 
A building has a direct impact on the environment throughout its lifetime. During the construction and use phases, a lot of materials and energy are used, and much waste is generated. Property developers should seek to manage the damage caused by their activities, as sustainable construction can make a significant contribution to sustainable development and environmental sustainability due to the large scale of the construction industry. Sustainable building projects contribute to the creation of a sustainable environment, and such projects are increasingly being implemented in the real estate market.

Decarbonizing the buildings and construction sector is critical to achieve the Paris Agreement commitment and the United Nations Sustainable Developments Goals (SDGs). Increasing climate change has led the United Nations to impose binding requirements to reduce greenhouse gas emissions and take measures to ensure sustainability. In this context, the EU aims to be climate-neutral by 2050. This objective is at the heart of the European Green Deal initiative and in line with the EU's commitment to global climate action under the Paris Agreement [3].

With advances in technology, it is possible to design and build increasingly complex high-rise buildings. "High-rise buildings" can be considered as such when surpassing $25 \mathrm{~m}$ [4]. It can be assumed that higher buildings have bigger area, more premises, higher energy consumption and $\mathrm{CO}_{2}$ emissions, thus creating a bigger negative impact on environment. Generally, construction of high-rise buildings is expensive, takes a lot of time and requires extensive human resources. On the other hand, high-rise buildings are distinctive in that, because of their height and architecture, they have a direct impact on the landscape and social environment.

So far, reinforced concrete, steel and glass are the most common materials used in the construction of high-rise buildings for historical reasons. At the end of the 19th century towns were frequently affected by fires, leading to the introduction of fire protection measures in many countries of the world, including legal measures prohibiting the use of timber structures for the construction of high-rise buildings. Recently, rapid development of building technologies and introduction of advanced engineered timber products (e.g., glued laminated timber (glulam), cross-laminated timber (CLT)), the updating of constructionrelated regulations encouraged a revival, and resulted in the expansion, of multi-storey timber construction [5]. Building high-rise buildings in timber, as further explained, directly contributes to achievement of sustainable construction goals across the three dimensions of sustainability.

Timber construction is increasingly being proposed as a way to preserve nature and create a sustainable environment. Use of timber reduces the environmental impact of a building for several reasons: (1) wood is the only renewable construction material that requires very little energy for its processing; (2) all timber products store carbon; (3) timber emits less greenhouse gases in the production process and does not emit $\mathrm{CO}_{2}$ during the lifetime of the building; (4) timber products are reusable and recyclable [6-10].

A study by Börjesson and Gustavsson revealed that the primary energy input (mainly fossil fuels) in the production of building materials is about 60-80\% lower for timber frames compared to concrete frames [6]. According to Oliver et al., using wood substitutes could save $14 \%$ to $31 \%$ of global $\mathrm{CO}_{2}$ emissions and $12 \%$ to $19 \%$ of global fossil fuel consumption by using $34 \%$ to $100 \%$ of the world's sustainable wood growth [7]. Skullestad, Bohne and Lohne carried out a life cycle assessment of four buildings ranging from 3 to 21 storeys to compare the impact of reinforced concrete and timber structures on climate change. The results showed that timber structures have a 34-84\% lower impact on climate change than reinforced concrete structures [8]. From an energy efficiency perspective, wood is a good thermal insulator. Its use in construction reduces thermal bridging and increases the thermal resistance of walls. It was found that CLT can achieve energy savings of about $40 \%$ compared to traditional building systems such as concrete and light steel frames [9].

In addition to the aforementioned environmental benefits, timber construction also fits into the mindset of circular economy. When a building is no longer suitable for its current purpose, it can be transformed. For example, a commercial timber building can 
be converted into housing or vice versa. Therefore, transformation as a method gives building materials a second life and exclude construction waste [10]. If materials cannot be transformed, they can serve as resources to produce other engineered timber products. Finally, timber can be used as biofuel.

Timber construction also has numerous economic benefits, including generation of green jobs. Timber products are cost-effective, since they are structurally efficient, lightweight, easy and quick to install at the construction site [11]. Higher speed of assembly contributes to reduction of labour hours and project cost [12].

Socio-cultural aspects such as public acceptance and appreciation of a building are also important. According to Wallenius, studies carried out in Norway, Japan, Canada and Austria reveal that wood may have positive effects on the emotional state of people [13]. Living environments with timber structures cause a drop in blood pressure and pulse and have a calming effect [13].

As woodworking and construction technologies improve, the construction of high-rise timber buildings is gaining popularity worldwide. There is a need to look deeper at the design of modern high-rise timber buildings and assess their sustainability.

To make it easier to identify sustainable buildings in the market, various frameworks and standards have been developed. One of the first methods for assessing the environmental sustainability of buildings is BREEAM (Building Research Establishment Environmental Assessment Method), which was developed in 1990 by the British organisation BRE Global [14,15]. Another popular sustainable building rating system is LEED (Leadership in Energy and Environmental Design), which was developed by the United States Green Building Council (USGBC) in 1998 [16]. Other systems developed around the world are mostly applied at a national level, e.g., the German sustainable building standard DGNB (Deutsche Geselleshaft für Nachhhaltiges Bauen), the Australian Green Star, and the increasingly popular WELL standard. Some of the rating systems have already recognized sustainability of timber buildings. For instance, LEED gives additional credit points for building in certified wood [17].

On the other hand, many of the aforementioned sustainable building rating systems have been criticized for overemphasizing environmental aspects [18,19]. They are mainly limited to environmental and resource efficiency criteria and do not take into account socio-economic factors that are directly linked to sustainability. Furthermore, if timber buildings are assessed by different rating systems, it is difficult to compare their properties. Therefore, a system of specific assessment indicators has to be developed to compare and assess the sustainability of high-rise timber buildings.

As the concept of sustainability is holistic, the assessment system must include indicators with different levels of relevance and units of measurement. In the scientific literature, multi-criteria assessment methods are often chosen to comprehensively assess the sustainability of buildings across a wide range of criteria (e.g., [20-26]). However, assessment and comparison of modern high-rise timber buildings is very limited in the scientific literature. Žegarac Leskovar and Premrov [5] reviewed architectural and structural design typologies of multi-storey timber buildings in Europe, and three cases, i.e., the Limnologen complex, the Via Cenni social housing, and the Treet building, were analyzed in detail. Kuzmanovska et al. [4] presented emerging trends and typologies of high-rise timber buildings built after 2009. A preliminary multiple-criteria assessment of high-rise timber buildings was performed by the authors of present article. The contemporary timber buildings were evaluated in terms of economic and environmental efficiency [27]. However, the system of assessment criteria was limited to the seven most commonly used criteria. It can be concluded that there are almost no studies discussing the multi-criteria assessment of the sustainability of high-rise timber buildings.

The aim of the present study is to assess the sustainability of modern high-rise timber buildings using multi-criteria assessment methods.

The rest of the paper is organized as follows. Section 2 presents a hierarchical system of sustainability assessment indicators developed by the authors. Section 3 describes 
sustainability assessment methodology and multi-criteria methods, i.e., the Analytic Hierarchy Process (AHP) and Simple Additive Weighting (SAW). In Section 4 the proposed framework is applied to assess sustainability of six high-rise timber buildings. Section 5 discusses the results. General conclusions, limitations and future research directions are provided in Section 6.

\section{Literature Review on Sustainability Evaluation Indicators}

In order to assess the sustainability of modern high-rise timber buildings using multicriteria assessment methods, a system of indicators must be developed.

The concept of sustainable development rests on three equally important dimensions, namely environmental sustainability, economic sustainability, and social sustainability. According to Janjua et al. [28], "building sustainability involves "green building" design and construction, taking account of both environmental elements and economic benefits, along with social obligations to the society we live in". Therefore, when assessing the sustainability of high-rise timber buildings and setting indicators, it is important to take into account the three dimensions of sustainability mentioned above.

Many sustainability assessment indicators and frameworks were formulated to support decision-making processes and have been widespread internationally [29]. A literature review has revealed that different sustainability indicators are distinguished in various literature sources. Following an analysis of the literature, BREEAM and LEED certification systems, the most frequently used sustainability evaluation indicators, were selected, and some specific indicators related to high-rise timber buildings were added by the authors. Table 1 provides a description of these indicators and their measurement.

Table 1. Description of sustainability evaluation indicators.

\begin{tabular}{|c|c|c|}
\hline Indicator & References & Description \& Measurement \\
\hline \multicolumn{3}{|r|}{ Environmental indicators } \\
\hline $\begin{array}{l}\text { Reduced } \mathrm{CO}_{2} \text { emissions } \\
(\mathrm{E} 1)\end{array}$ & {$[14,16,19,30-32]$} & $\begin{array}{l}\text { Reduced } \mathrm{CO}_{2} \text { emissions to the atmosphere when comparing a timber-framed building } \\
\text { with a similar reinforced concrete building. The unit of measurement is tons. The bigger } \\
\text { the difference, the less negative environmental impact the building has. }\end{array}$ \\
\hline $\begin{array}{l}\text { Reduced waste during } \\
\text { construction (E2) }\end{array}$ & {$[14,31]$} & $\begin{array}{l}\text { Prefabricated, modular construction technologies produce less waste than conventional } \\
\text { construction methods. The less waste generated during construction, the less negative } \\
\text { impact the building has on the natural environment. The unit of measurement is points } \\
\text { (3 points-modular construction is applied, all elements are brought to the construction } \\
\text { site ready for installation, many works are carried out in the factory (windows are } \\
\text { installed, plumbing equipment, finishing is carried out, a minimum amount of waste is } \\
\text { generated; } 2 \text { points-prefabricated construction is used, only a small amount of waste is } \\
\text { generated; } 1 \text { point-prefabricated construction is applied, all elements are brought to the } \\
\text { construction site ready for installation, but the amount of construction waste is higher } \\
\text { because part of the building is made of reinforced concrete. }\end{array}$ \\
\hline $\begin{array}{l}\text { Possibility of reusing } \\
\text { structures after building } \\
\text { demolition (E3) }\end{array}$ & {$[14,19,33]$} & $\begin{array}{l}\text { Possible reuse or recycling of building structures, which reduces the negative impact on } \\
\text { the environment during demolition of the building. In the case of prefabricated } \\
\text { construction, the use of timber elements decreases the number of chemical connections. } \\
\text { Mechanical joints are easier to disassemble; the structures remain intact and can be } \\
\text { reused. Also, less dust is generated during the demolition of the building. The unit of } \\
\text { measurement is points ( } 3 \text { points-the building's timber structures are prefabricated, } \\
\text { modular and have almost no reinforced concrete; } 2 \text { points-the building's timber } \\
\text { structure is prefabricated, modular, with reinforced concrete ground floor or rigid cores; } \\
1 \text { point-the building's timber structures are prefabricated, modular, with several floors } \\
\text { and reinforced concrete rigid cores). }\end{array}$ \\
\hline $\begin{array}{l}\text { Preserving the natural } \\
\text { environment around the } \\
\text { building (E4) }\end{array}$ & {$[15,16,30,34]$} & $\begin{array}{l}\text { Impact of the building on the local natural environment. The unit of measurement is } \\
\text { points ( } 3 \text { points-the project preserves the natural environment and creates pedestrian } \\
\text { paths; } 2 \text { points—-the project has no significant impact on the environment, new plants are } \\
\text { planted on the site, footpaths are created; } 1 \text { point-after the project, most of the site is } \\
\text { covered with pavements (tiles, cobblestones, asphalt), with few plants). }\end{array}$ \\
\hline
\end{tabular}


Table 1. Cont.

\begin{tabular}{|c|c|c|}
\hline Indicator & References & Description \& Measurement \\
\hline $\begin{array}{l}\text { Energy consumption } \\
\text { (E5) }\end{array}$ & {$[5,15,16,19,30]$} & $\begin{array}{l}\text { Annual energy consumption per square meter of a building. The smaller the value, the } \\
\text { more energy-efficient the building is and the less negative the impact on the natural } \\
\text { environment. Unit of measurement }-\mathrm{kWh} / \mathrm{m}^{2} \text { per year. }\end{array}$ \\
\hline $\begin{array}{l}\text { Renewable energy } \\
\text { deployment (E6) }\end{array}$ & {$[15,16,30,35]$} & $\begin{array}{l}\text { Deployment of renewable energy systems (solar, wind, geothermal). The unit of } \\
\text { measurement is points ( } 3 \text { points-the building has several renewable energy systems } \\
\text { (solar panels, wind turbine, geothermal heating) and electric car charging stations; } \\
2 \text { points-the building is equipped with at least one such system; } 1 \text { point- there are no } \\
\text { such systems in the building, or there is no record of installed systems). }\end{array}$ \\
\hline $\begin{array}{l}\text { Use of local raw materials } \\
\text { (E7) }\end{array}$ & {$[19,30,31,33]$} & $\begin{array}{l}\text { Building materials which are manufactured within a defined radius or produced locally } \\
\text { using raw materials obtained within a defined radius. Unit of measurement-points } \\
\text { (5 points-using building materials from local sources less than } 100 \mathrm{~km} \text { away; } \\
4 \text { points-101-500 km away, } 3 \text { points- } 501-1000 \mathrm{~km} \text { away; } 2 \text { points-1001-1500 km } \\
\text { away, } 1 \text { point-more than } 1500 \mathrm{~km} \text { away). }\end{array}$ \\
\hline
\end{tabular}

Heat transfer coefficient

of the external envelope (E8)

$[5,15,16,19,32] \quad$ The heat transfer coefficient, measured by $U$-value. Unit of measurement- $W / \mathrm{m}^{2} \mathrm{~K}$.

Amount of wood used
$($ E9) $\quad[5,19,36]$

Using certified wood (E10)

$[16,19,32,33]$$$
(\mathrm{E} 10)
$$

\section{Sustainability certification \\ (LEED, BREEAM, etc.)} (E11) Relative value indicating the proportion of used timber structures $\left(\mathrm{m}^{3}\right)$ per square meter
of the building.

The building materials are made from wood that is certified and sourced from replanted forests. The unit of measurement is points (3 points—the timber used for the building's construction is certified by the Forest Stewardship Council (FSC) or other authorized certification body, and some of the structures are made from recycled wood waste;

2 points—-the wood used for the building's construction is certified; 1 point- the wood is not certified).

The building is certified for sustainability (LEED, BREEAM or other) and meets international or global environmental standards. The unit of measurement is points (3 points - the building is LEED, BREEAM, Green Star or other certified; 2 points-the building has been designed to one of these standards but has not yet received it; 1 point-the building is not certified).

\begin{tabular}{|c|c|c|}
\hline \multicolumn{3}{|r|}{ Economic/technological indicators } \\
\hline Building height (ET1) & [5] & Architectural height of the building (meters). \\
\hline $\begin{array}{l}\text { Number of floors in the } \\
\text { building (ET2) }\end{array}$ & [5] & $\begin{array}{l}\text { The number of floors above ground in a building; sometimes buildings of the same } \\
\text { height may have different numbers of floors. The more floors, the larger the area of the } \\
\text { building that can be sold/leased. The unit of measurement is the number of floors. }\end{array}$ \\
\hline $\begin{array}{l}\text { Cost of implementing the } \\
\text { project (ET3) }\end{array}$ & {$[11,12,16,30]$} & $\begin{array}{l}\text { The ratio of the project's implementation cost to the project's } \\
\text { gross floor area. The lower the cost, the more cost-effective the project is. Unit of } \\
\text { measurement-EUR } / \mathrm{m}^{2} \text {. }\end{array}$ \\
\hline $\begin{array}{l}\text { Installation time of the } \\
\text { structures (ET4) }\end{array}$ & {$[11,12]$} & $\begin{array}{l}\text { The time taken to install the load-bearing structures of one floor of the building. The } \\
\text { shorter the installation time, the more cost-effective the construction of the building. } \\
\text { Unit of measurement-floor/day. }\end{array}$ \\
\hline $\begin{array}{l}\text { Duration of the project } \\
\text { (ET5) }\end{array}$ & {$[11,12]$} & $\begin{array}{l}\text { The time taken to complete the project. The shorter the time, the more successful the } \\
\text { project. The unit of measurement is months. }\end{array}$ \\
\hline \multicolumn{3}{|r|}{ Social indicators } \\
\hline $\begin{array}{l}\text { Indoor acoustic comfort } \\
\qquad(\mathrm{S} 1)\end{array}$ & {$[14-16,30,32,34]$} & $\begin{array}{l}\text { Ensuring the acoustic comfort. The unit of measurement is points ( } 3 \text { points-the sound } \\
\text { class of the premises meets the requirements of class } \mathrm{B}(<55 \mathrm{~dB}) \text {, the materials used are } \\
\text { sound absorbing, resulting in maximum acoustic comfort; } 2 \text { points- the sound class of } \\
\text { the premises meets the requirements of class } C(\geq 55 \mathrm{~dB}) \text {, the materials used are sound } \\
\text { absorbing, which creates acoustic comfort; } 1 \text { point- data on the sound class of building } \\
\text { envelope components are not available, but the solutions implemented in the project } \\
\text { meet the requirements for sound class, the materials used suppress the } \\
\text { generated sounds). }\end{array}$ \\
\hline $\begin{array}{l}\text { Building location, } \\
\text { accessibility (S2) }\end{array}$ & {$[14,30,34]$} & $\begin{array}{l}\text { Assessment of the location of the building, taking into account the accessibility of the } \\
\text { site, the infrastructure, the distances to the main social facilities, and the transport links. } \\
\text { The unit of measurement is points ( } 3 \text { points-within } 5 \mathrm{~km} \text { there is a school, kindergarten, } \\
\text { shop, public transport stops, good access by car, the building is close to major cities; } \\
2 \text { points-the nearest school, kindergarten, shop, public transport stops can be reached } \\
\text { within } 10 \mathrm{~km} \text {, with good access by car; } 1 \text { point-more than } 10 \mathrm{~km} \text { from the nearest } \\
\text { school, kindergarten, shop, public transport stop). }\end{array}$ \\
\hline
\end{tabular}


Table 1. Cont.

\begin{tabular}{|c|c|c|}
\hline Indicator & References & Description \& Measurement \\
\hline $\begin{array}{l}\text { Indoor microclimate, } \\
\text { comfort (S3) }\end{array}$ & {$[14-16,30]$} & $\begin{array}{l}\text { An indicator that measures a person's psychological state and productivity in a given } \\
\text { environment. It has been scientifically proven that working and living in an } \\
\text { environment with timber elements reduces stress, and improves a person's } \\
\text { psychological state, productivity and mood. The unit of measurement is points } \\
\text { (5 points-exterior and interior timber structures of the building are exposed as interior } \\
\text { details, additional timber elements predominate in the finishing; } 4 \text { points-the internal } \\
\text { timber structures have been retained as interior fittings; } 3 \text { points-timber structures are } \\
\text { hidden, but timber elements dominate the decoration of the common areas; } \\
2 \text { points-timber structures are hidden, timber elements predominate in the decoration } \\
\text { of the apartment; } 1 \text { point-finishing is done without using timber details). }\end{array}$ \\
\hline $\begin{array}{l}\text { Aesthetic appearance of } \\
\text { the building (S4) }\end{array}$ & {$[16,19]$} & $\begin{array}{l}\text { An indicator assessing a building's aesthetics, architectural idea, and the overall } \\
\text { architecture of the dominant buildings in the city. Measured by points ( } 3 \text { points-the } \\
\text { building fits perfectly into the city's architecture; } 2 \text { points-the building stands out from } \\
\text { the surrounding buildings but does not have a negative impact; } 1 \text { point-the building } \\
\text { does not correspond at all to the architecture or elements of the buildings prevailing in } \\
\text { the area). }\end{array}$ \\
\hline Project awards (S5) & Added by authors & $\begin{array}{l}\text { An indicator that measures the awards a building has received. Measured by points } \\
\text { ( } 3 \text { points-received awards for adapted technologies, new world-class achievements; } \\
2 \text { points-received awards for adapted technologies, new local achievements; } \\
1 \text { point-the building has not won any awards). }\end{array}$ \\
\hline Fire resistance (S6) & [19] & $\begin{array}{l}\text { An indicator assessing the ability of the building envelope to withstand minutes of fire, } \\
\text { and additional fire protection measures installed. Measured by points ( } 5 \text { points-the } \\
\text { load-bearing structures can withstand } 120 \text { min of fire, a sprinkler system has been } \\
\text { installed; } 4 \text { points— } 90 \text { min., a sprinkler system has been installed; } 3 \text { points- } 60 \text { min., a } \\
\text { sprinkler system has been installed; } 2 \text { points }->60 \text { min, no additional fire-fighting } \\
\text { measures; } 1 \text { point - the building does not meet fire safety requirements). }\end{array}$ \\
\hline $\begin{array}{l}\text { Spaces for communities } \\
\text { (S7) }\end{array}$ & {$[32]$} & $\begin{array}{l}\text { An indicator of the extent to which a building supports creation of communities, i.e., } \\
\text { whether common spaces are created around or within a building. Measured by points } \\
\text { (3 points-the building provides meeting spaces for communities beyond the building's } \\
\text { occupants, such as a shared terrace, a sports club or a café, so that people can live and } \\
\text { work in the same building, and the environment has been landscaped with new } \\
\text { pedestrian walkways and parks; } 2 \text { points-creating common spaces for the building's } \\
\text { residents only, landscaping the environment; } 1 \text { point-the building does not add any } \\
\text { social value, there are no common spaces). }\end{array}$ \\
\hline
\end{tabular}

\section{Materials and Methods}

In order to assess the sustainability of high-rise timber buildings, a multi-criteria assessment was chosen because it allows for all aspects of sustainability to be taken into account: environmental, economic and social, to determine the significance of selected indicators, as well as to compare values with different units.

Figure 1 shows the developed sustainability assessment methodology, which consists of four basic steps.

Step 1-determining significance of the indicators. The Analytic Hierarchy Process (AHP) method by Saaty [37] was chosen to determine the significance of the indicators. As proven in literature, the AHP is a useful method for weighting sustainability indicators as it allows for the creation of a hierarchical system of evaluation indicators, which is aligned with the structures of most sustainability frameworks; it is simple and flexible; and it provides a consistent verification [38,39]. It shall be noted that there is no rule for appropriate number of experts in AHP. It depends on specialized expertise.

A questionnaire based on pair-wise comparisons was developed to determine the significance of the selected indicators (see Table 1 ) and provided to six experts by e-mail. The survey involved 4 experts working in national and international timber design and construction companies and 2 academics whose research area is related to sustainable construction. All experts had 10 to 20 years' experience in their field. Based on their knowledge and expertise, the experts assessed the sustainability indicators and distinguished the most important ones. 
According to the AHP method, indicators were compared in pairs by each expert and assessed using a scale of 1-9 from equally important (value of 1) to extremely most important (value of 9).

Judgment matrices, as filled out by experts, were used for the calculation of the indicators' significance [37]:

$$
q_{i}=\frac{\left(\prod_{j=1}^{m} c_{i j}\right)^{\frac{1}{m}}}{\sum_{k=1}^{m}\left(\prod_{j=1}^{m} c_{k j}\right)^{\frac{1}{m}}},
$$

and

$$
\lambda_{\text {max }}=\sum_{i=1}^{m}\left\{\left(\sum_{j=1}^{m} c_{i j}\right) \times q_{i}\right\},
$$

where: $k$-number of experts; $m$-number of indicators; $c_{i}$-ith determinant; $q_{i}$-significance (weight) of the $i$ th indicator; $\lambda$-eigenvalue.

The consistency ratio (CR) of each matrix was checked [37]:

$$
C R=\frac{C I}{R I},
$$

where: $R I-$ random consistency index and $C I-$ consistency index. Acceptable $C R$ values are 0.05 for a 3-by-3 matrix, 0.08 for a 4-by-4 matrix and 0.1 for larger matrices [37].

Further significances determined by each of the experts were aggregated and assumed as distribution and the mean values of these distributions were calculated in order to determine the final significance of the indicators (see Section 4.1). An open source BPMSG AHP Online System [40] was used for calculations.

To ensure consistency of experts' opinions, Kendall's coefficient of concordance was calculated [41]:

$$
W=\frac{12 S}{r^{2}\left(m^{3}-m\right)} ; W \in[0 ; 1],
$$

where $S$ is the total square deviation of the rankings of each indicator, $r$ - the number of experts and $m$-the number of indicators.

The significance $\chi^{2}$ of the concordance coefficient was calculated as follows [41]:

$$
\chi_{\alpha, v}^{2}=W r(m-1) .
$$

If the calculated value $\chi^{2}$ is larger than the critical tabular value $\chi_{\text {crit }}^{2}$ for the preselected level of significance (e.g., $\alpha=0.05$ ), then the hypothesis about the agreement of independent experts' 'judgments' is not rejected [41].

Step 2-analysis of the buildings and determination of values of indicators. Six high-rise timber buildings were selected for analysis. Values of the indicators have been determined by using publicly available information (see Section 4.2).

Step 3-multi-criteria sustainability assessment of the buildings (see Section 4.3). For this purpose, the Simple Additive Weighting (SAW) method, summarized by MacCrimmon in 1968 [42], was selected. It is one of the oldest, most widely known, simplest and most practically used multi-criteria assessment methods. It allows for the integration of values of indicators and their significances into a single magnitude by calculating the efficiency index $R_{j}$ of each building alternative:

$$
R_{j}=\sum_{j=1}^{n} q_{i} \bar{x}_{i j}
$$

where $q_{i}$ is the weight of the $i$ th indicator; $\bar{x}_{i j}$-normalized attribute value of the $j$ th alternative. 
Step 4-ranking of the buildings, conclusions and recommendations. Based on determined efficiency indexes, the buildings were ranked - the higher the efficiency index, the higher the rank.

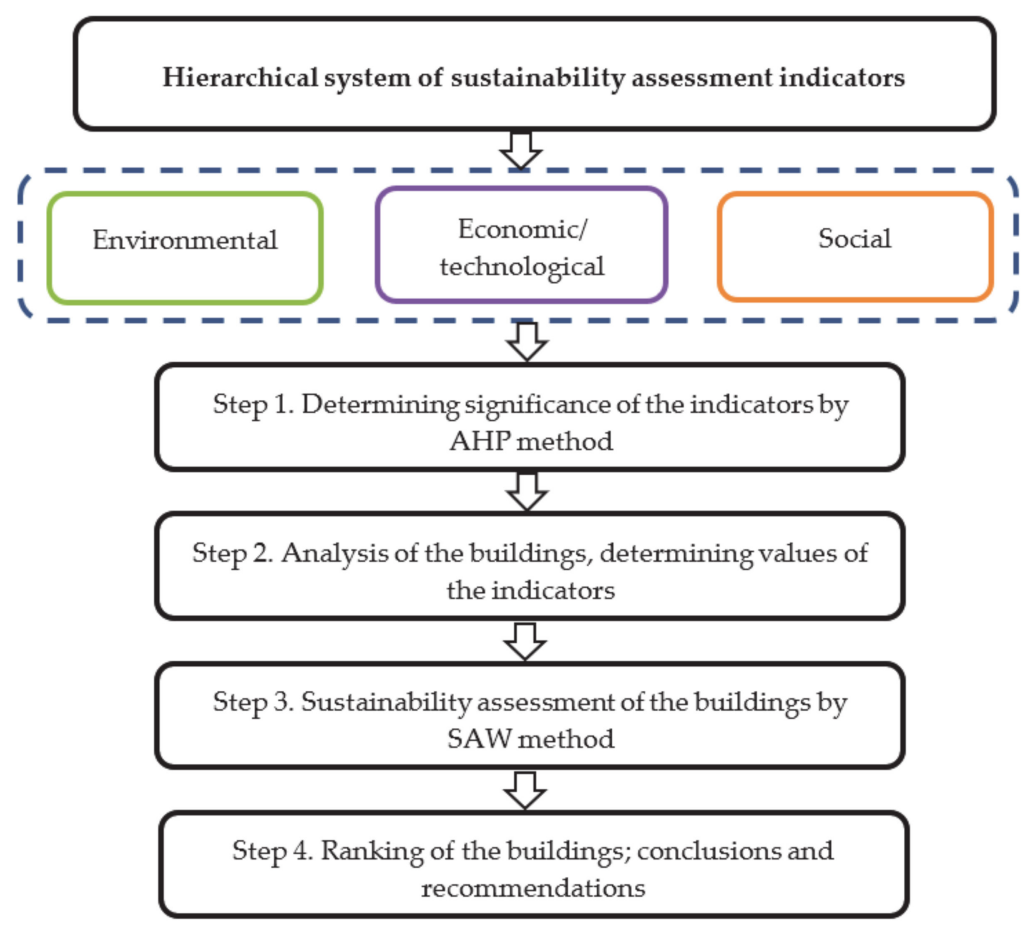

Figure 1. Sustainability assessment methodology.

\section{Results}

\subsection{Significance of the Indicators}

Significance of the indicators was assessed using an expert survey and the AHP method (see Table 2).

Table 2. Significance of sustainability evaluation indicators.

\begin{tabular}{|c|c|c|c|c|c|c|c|c|}
\hline \multirow[t]{2}{*}{ Dimension } & \multirow[t]{2}{*}{ Indicator } & \multicolumn{6}{|c|}{ Experts' Evaluation } & \multirow[b]{2}{*}{ Significance } \\
\hline & & Exp1 & Exp2 & Exp3 & Exp4 & Exp5 & Exp6 & \\
\hline \multirow{12}{*}{ Environmental } & E1 & 0.072 & 0.022 & 0.045 & 0.056 & 0.091 & 0.067 & 0.059 \\
\hline & E2 & 0.043 & 0.092 & 0.053 & 0.055 & 0.021 & 0.02 & 0.047 \\
\hline & E3 & 0.093 & 0.042 & 0.082 & 0.032 & 0.082 & 0.173 & 0.084 \\
\hline & $\mathrm{E} 4$ & 0.033 & 0.013 & 0.046 & 0.032 & 0.024 & 0.027 & 0.029 \\
\hline & E5 & 0.094 & 0.161 & 0.068 & 0.270 & 0.130 & 0.058 & $\underline{0.130 *}$ \\
\hline & E6 & 0.157 & 0.285 & 0.092 & 0.197 & 0.276 & 0.225 & $\underline{0.205}$ \\
\hline & E7 & 0.028 & 0.105 & 0.13 & 0.022 & 0.047 & 0.042 & 0.062 \\
\hline & E8 & 0.024 & 0.058 & 0.033 & 0.131 & 0.010 & 0.129 & 0.079 \\
\hline & E9 & 0.069 & 0.021 & 0.117 & 0.015 & 0.037 & 0.08 & 0.057 \\
\hline & E10 & 0.126 & 0.03 & 0.197 & 0.016 & 0.043 & 0.077 & 0.082 \\
\hline & E11 & 0.261 & 0.171 & 0.137 & 0.174 & 0.149 & 0.102 & $\underline{0.166}$ \\
\hline & $C R, \%$ & 6.9 & 8.7 & 9.2 & 8.9 & 8.4 & 8.5 & $\Sigma=1.000$ \\
\hline
\end{tabular}


Table 2. Cont.

\begin{tabular}{|c|c|c|c|c|c|c|c|c|}
\hline Dimension & Indicator & & & Experts & luation & & & \\
\hline \multirow{6}{*}{$\begin{array}{l}\text { Economic/ } \\
\text { Technological }\end{array}$} & ET1 & 0.032 & 0.064 & 0.032 & 0.201 & 0.044 & 0.117 & 0.082 \\
\hline & ET2 & 0.085 & 0.045 & 0.081 & 0.166 & 0.066 & 0.276 & 0.120 \\
\hline & ET3 & 0.472 & 0.296 & 0.421 & 0.464 & 0.351 & 0.188 & $\underline{0.365}$ \\
\hline & ET4 & 0.244 & 0.482 & 0.336 & 0.109 & 0.358 & 0.187 & $\underline{0.286}$ \\
\hline & ET5 & 0.167 & 0.113 & 0.130 & 0.060 & 0.181 & 0.232 & $\underline{0.147}$ \\
\hline & $C R, \%$ & 5.9 & 5.1 & 6.2 & 4.2 & 7.2 & 7.3 & $\Sigma=1.000$ \\
\hline & \multicolumn{8}{|c|}{$W=0.428 ; \chi^{2} \geq \chi_{c r i t}^{2}=10.267>9.488$} \\
\hline \multirow{9}{*}{ Social } & S1 & 0.098 & 0.037 & 0.112 & 0.010 & 0.074 & 0.065 & 0.081 \\
\hline & S2 & 0.126 & 0.175 & 0.130 & 0.378 & 0.227 & 0.089 & $\underline{0.188}$ \\
\hline & S3 & 0.181 & 0.132 & 0.272 & 0.267 & 0.083 & 0.241 & $\underline{0.196}$ \\
\hline & S4 & 0.050 & 0.155 & 0.037 & 0.065 & 0.032 & 0.093 & 0.072 \\
\hline & S5 & 0.023 & 0.143 & 0.021 & 0.018 & 0.022 & 0.081 & 0.051 \\
\hline & S6 & 0.467 & 0.078 & 0.351 & 0.149 & 0.409 & 0.290 & $\underline{0.291}$ \\
\hline & S7 & 0.055 & 0.280 & 0.077 & 0.023 & 0.153 & 0.140 & 0.121 \\
\hline & $C R, \%$ & 4.4 & 8.3 & 7.8 & 8.7 & 8.0 & 7.5 & $\Sigma=1.000$ \\
\hline & \multicolumn{8}{|c|}{$W=0.528 ; \chi^{2} \geq \chi_{c r i t}^{2}=19.000>12.592$} \\
\hline
\end{tabular}

Notes: Exp $=$ expert. * The most significant indicators are highlighted.

The hierarchical system of sustainability indicators is provided in Figure 2.

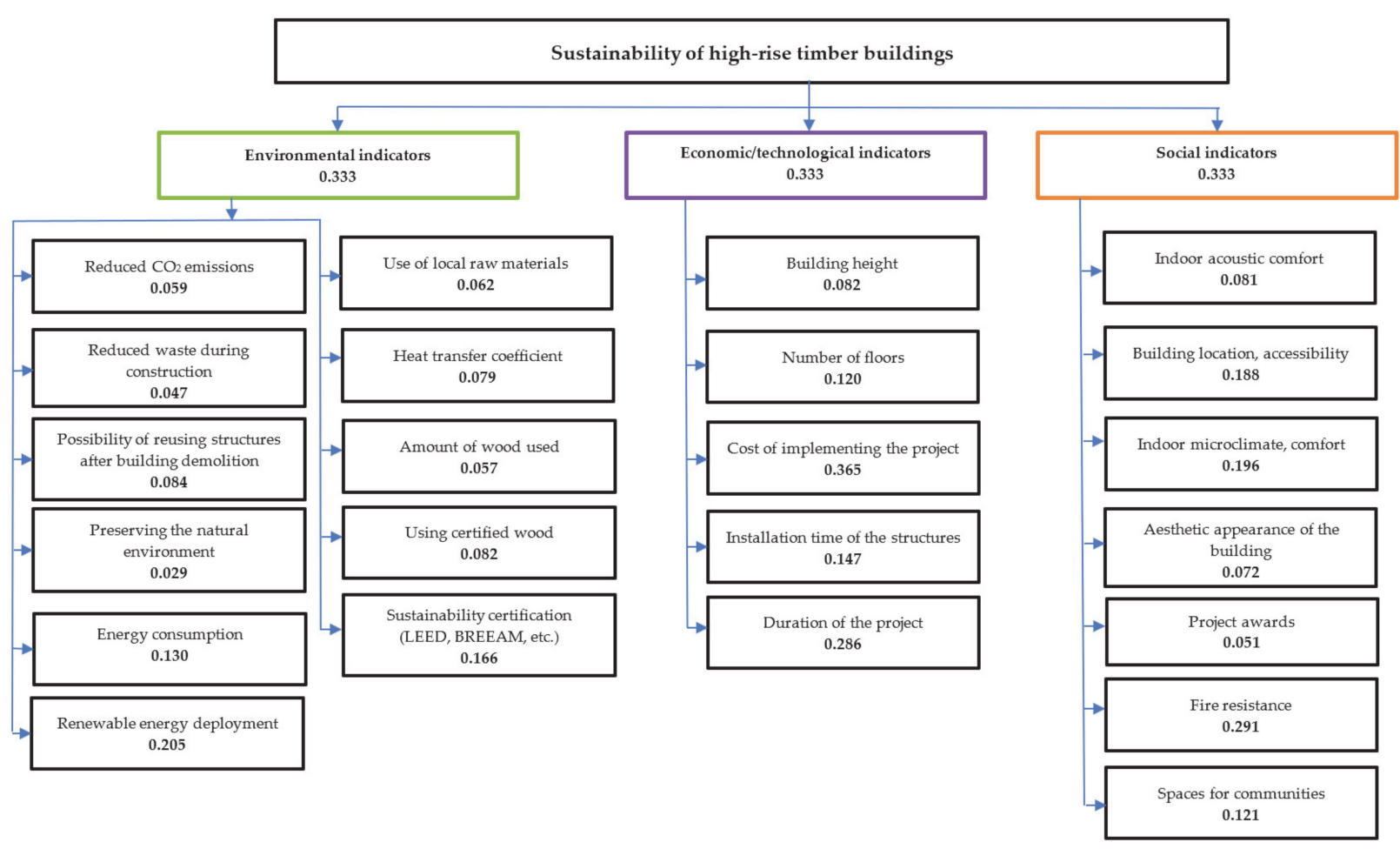

Figure 2. Hierarchical system of sustainability indicators.

The key environmental indicators identified are: renewable energy deploymentsignificance level 0.205 , sustainability certification (LEED, BREEAM or other) -0.166 , and energy consumption -0.130 . 
In the economic/technological category, the most significant indicators are the cost of the project with a significance of 0.365 , the duration of the project with a significance of 0.286 , and the duration of the installation of the structure with a significance of 0.147 .

The most important social indicators, in accordance with the experts, are the fire resistance of the building - 0.291 , the indoor microclimate, comfort -0.196 and the location of the building, accessibility- 0.188 .

It is assumed that all sustainability dimensions are of equal importance and therefore have equal significance, i.e., environmental, social and economic/technological dimensions have a significance of 0.333 .

\subsection{Description of the High-Rise Timber Buildings to Be Assessed}

In light of the multi-criteria evaluation indicators chosen, a description of the buildings to be compared is given below. Six sites in different parts of the world were selected for multi-criteria evaluation: Mjøstårnet (Norway), Brock Commons (Canada), Treet (Norway), Forte (Australia), Strandparken (Sweden) and Stadthaus (UK).

Mjøstårnet or The Mjos Tower (A1) is a mixed-use building in Norway. In 2020 it was the tallest timber-framed building in the world. The main characteristics of the building are provided in Table 3.

Mjøstårnet is located in the small town of Brumunddal in Norway, about $140 \mathrm{~km}$ from Oslo, next to the motorway on the shores of Norway's largest lake, Mjøsa.

The impact of the building on the area is positive, i.e., there is a parking lot, pedestrian paths, lighting of the territory, new trees planted, shrubs, and herbaceous plants. Public gardens and outdoor spaces connected to pedestrian paths and bicycle paths are located near the lake. This multi-storey building is of special landscape significance because of its proximity to Norway's largest lake, and the building, which can be seen from afar, has quickly become an important symbol of the city. The Mjøstårnet tower looks like a tree, with pine cladding and support columns made of wooden beams, and fits perfectly into the landscape of the area, looking aesthetic.

The project has made a positive contribution to the social development of the region. The building is mixed-use, with offices, 33 apartments, 72 hotel rooms, a conference room and a roof terrace. The roof terrace is open to residents, hotel guests and staff, while other guests can access it with a ticket. The ground floor is open to the public and includes a lobby, reception and restaurant. There is also a public bath and two 25-metre swimming pools on the ground floor. This creates shared public spaces accessible to all, where communities can meet [43]. The city of Bruumiundal was notorious for its crime in the 1990s, where one third of all racist attacks in Norway took place. It is expected that a new high-rise timber building will attract more tourists and investors. It is also planned to construct three lower multi-storey buildings of a similar type next to each other in the future [43].

Table 3. Characteristics of the Mjøstårnet (developed by the authors based on [44-46]).

\begin{tabular}{cc}
\hline Item & Value \\
\hline Year of completion & 2019 \\
Height, meters & 85.4 \\
Number of storeys & 18 \\
Total area, $\mathrm{m}^{2}$ & 11,300 \\
Cost of the project, million EUR & $51.15(4.82$ million for construction of \\
Timber structures & the building) \\
Quantity of wood used, $\mathrm{m}^{3}$ & 2600 \\
Timber certification & FSC certified, complies with the \\
& European Union Timber Regulation \\
& (EUTR) \\
\hline
\end{tabular}


Table 3. Cont.

\begin{tabular}{cc}
\hline Item & Value \\
\hline Duration of construction, months & 24 \\
Energy class & $\begin{array}{c}\text { Energy class A in accordance with the } \\
\text { Norwegian standard NS } 3701\end{array}$ \\
External envelope heat transfer coefficient (U-value, \\
$\mathrm{W} / \mathrm{m}^{2} \mathrm{~K}$ )
\end{tabular}

Brock Commons (A2) is a student residence building at the University of British Columbia (UBC) in Vancouver, Canada. The main characteristics of the building are provided in Table 4.

Table 4. Characteristics of Brock Commons (developed by the authors based on [47-50]).

\begin{tabular}{|c|c|}
\hline Item & Value \\
\hline Year of completion & 2017 \\
\hline Height, meters & 54 \\
\hline Number of storeys & 18 \\
\hline Total area, $\mathrm{m}^{2}$ & 15,120 \\
\hline Cost of the project, million EUR & 36.34 \\
\hline Timber structures & CLT panels supported on glulam columns \\
\hline Quantity of wood used, $\mathrm{m}^{3}$ & 2233 \\
\hline Timber certification & FSC certified \\
\hline Duration of construction, months & 20 \\
\hline Energy class & $\mathrm{N} / \mathrm{A}$ (there are no energy classes in Canada) \\
\hline $\begin{array}{l}\text { External envelope heat transfer coefficient } \\
\left.\text { (U-value, } \mathrm{W} / \mathrm{m}^{2} \mathrm{~K}\right)\end{array}$ & in \\
\hline Energy consumption, $\mathrm{kWh} / \mathrm{m}^{2}$ per year & 135 \\
\hline $\begin{array}{l}\text { Reduction of } \mathrm{CO}_{2} \text { emissions compared to } \\
\text { reinforced concrete construction, tons }\end{array}$ & 2432 \\
\hline Use of renewable energy sources & No data \\
\hline Sustainability certificates & $\begin{array}{l}\text { LEED Gold BD + C for new construction } \\
\text { Wood Design and Building 2017, Fast } \\
\text { Company Innovation by Design 2017, } \\
\text { Favourite Projects of the Year } 2017 \\
\text { Construction Dive Five, National Council of } \\
\text { Structural Engineers Associations Award for } \\
\text { Excellence in Structural Engineering 2017, } \\
\text { Canadian Wood Council Wood Products } \\
\text { Awards } 2018 \text { (Architect's Award, Engineer's } \\
\text { Award, Innovation Award) }\end{array}$ \\
\hline
\end{tabular}

The use of prefabricated elements in the building's construction has reduced the amount of waste on site by about two thirds, but as in the Mjøstårnet project, not only timber structures have been used, i.e., 1st and 2 nd floors and the elevator shafts are made of reinforced concrete. The structures were manufactured $430 \mathrm{~km}$ away from the site. Local materials (38\%) and recycled materials (19\%) were used to make the structures.

The impact of the building on the area is positive; the environment around the building is arranged, i.e., pedestrian paths, lighting of the territory, and the territory is planted. A 
forest near the university campus has created a lasting harmony with the tree [51]. The building's architecture is in harmony with the nearby dormitories.

The project has made a positive contribution to the social development of the territory. The building is equipped with more than 400 student rooms, study and common areas, and lounges.

The information collected by the Building Management System (BMS) allows operators to assess the performance of the system and check air quality and temperature. In order to continuously improve living conditions for students, the University conducts an annual survey that assesses staff, dormitory accessibility, noise levels in the building, building design, lighting, indoor air quality, thermal comfort and acoustics [47]. Timber elements predominate in the decoration of the rooms and common areas, with exposed timber structures in some places.

Treet or The Tree (A3) is a 14-storey residential timber building in Bergen, Norway. The main characteristics of the building are provided in Table 5 .

Table 5. Characteristics of the Treet (developed by the authors based on [52-54]).

\begin{tabular}{cc}
\hline Item & Value \\
\hline Year of completion & 2015 \\
Height, meters & 52.8 \\
Number of storeys & 14 \\
Total area, $\mathrm{m}^{2}$ & 58,300 \\
Cost of the project, million EUR & 22 \\
Timber structures & Glulam and CLT \\
Quantity of wood used, $\mathrm{m}^{3}$ & 935 \\
Timber certification & FSC certified, complies with the EUTR \\
Euration of construction, months & regulation \\
Energy class & 20 \\
External envelope heat transfer coefficient & Passive house and energy class A in accordance \\
(U-value, $\mathrm{W} / \mathrm{m}^{2} \mathrm{~K}$ ) & with the Norwegian standard NS 3700/3701 \\
Energy consumption, $\mathrm{kWh} / \mathrm{m}^{2}$ per year & 0.12 \\
Reduction of CO $\mathrm{O}_{2}$ emissions compared to & 84 \\
reinforced concrete construction, tons & 2000 \\
Use of renewable energy sources & No data \\
Sustainability certificates & No data \\
Awards & Construction of the Year Award 2015
\end{tabular}

The building is located in the central part of the city of Bergen. Bergen is the second largest city on the west coast of Norway. The building is located near a large bridge that crosses the Puddefjorden fjord [53].

The building has a positive impact on the area, with landscaping, pedestrian walkways and lighting. The building fits perfectly into its surroundings. In recent decades, the technology developed to build timber bridges has been applied to the construction of the building, making it similar to the nearby bridge [54]. The building fits well into the landscape of the area and its architecture is aesthetically pleasing. There is a terrace at the top of the building on the 13th and 14th floors and a gym on the 9th floor with views of the city and the fjords. Only 25 parking spaces were provided for 62 apartments, thus promoting the sharing economy.

To create a comfortable environment, the interior of the apartments has been left with exposed timber structures. To reduce the building's fluctuations, giving more weight to the building, concrete slabs were cast to increase the comfort of the people living on the upper floors.

Forte (A4) is a nine-storey timber building in Australia. The main characteristics of the building are provided in Table 6. 
Table 6. Characteristics of Forte (developed by authors based on [55]).

\begin{tabular}{cc}
\hline Item & Value \\
\hline Year of completion & 2012 \\
Height, meters & 32.2 \\
Number of storeys & 9 \\
Total area, $\mathrm{m}^{2}$ & 1900 \\
Cost of the project, million EUR & 9.87 \\
Timber structures & Cross-laminated timber panels \\
Quantity of wood used, $\mathrm{m}^{3}$ & 883 \\
Timber certification & PEFC (Programme for the Endorsement of \\
Duration of construction, months & Forest Certification) \\
Energy class & 11 \\
External envelope heat transfer coefficient & Not available \\
(U-value, W/m ${ }^{2}$ K) & 0.13 \\
Energy consumption, $\mathrm{kWh} / \mathrm{m}^{2}$ per year & 144 \\
Reduction of CO ${ }_{2}$ emissions compared to & 1451 \\
reinforced concrete construction, tons & No data \\
Use of renewable energy sources & No data \\
Sustainability certificates & Awards
\end{tabular}

The Forte building has a positive impact on the area, with landscaping around the building, such as pedestrian paths, lighting and new landscaping. The architecture of the building fits in with the surrounding buildings and the landscape of the area and has an aesthetic appearance. There are four luxury townhouses in the neighborhood. The buildings reflect the contemporary urban lifestyle of Victoria Harbour [55].

The project contributed to the social development of the region. It has 23 apartments and a commercial space on the ground floor, allowing residents to work, live and socialize in one building. There is a community garden nearby and vegetables are grown on the balconies. Each apartment is designed to maximize sunlight and natural ventilation. The interior has been left with open cross-laminated timber wall panel structures, and the finishing is dominated by timber elements.

Strandparken (A5) is an 8-storey apartment building located in the small Stockholm suburb of Sundbyberg, Sweden. The main characteristics of the building are provided in Table 7.

Table 7. Characteristics of the Strandparken (developed by the authors based on [56-58]).

\begin{tabular}{cc}
\hline Item & Value \\
\hline Year of completion & 2014 \\
Height, meters & 25.0 \\
Number of storeys & 8 \\
Total area, $\mathrm{m}^{2}$ & 4300 \\
Cost of the project, million EUR & 8.16 \\
Timber structures & 1290 \\
Quantity of wood used, $\mathrm{m}^{3}$ & Cross-laminated timber panels \\
Timber certification & 20 \\
Duration of construction, months & Passive house in accordance with the \\
Energy class & FEBY12 standard \\
External envelope heat transfer coefficient & 0.16 \\
(U-value, $\mathrm{W} / \mathrm{m}^{2} \mathrm{~K}$ ) & 65 \\
Energy consumption, $\mathrm{kWh} / \mathrm{m}^{2}$ per year &
\end{tabular}


Table 7. Cont.

\begin{tabular}{cc}
\hline Item & Value \\
\hline $\begin{array}{c}\text { Reduction of } \mathrm{CO}_{2} \text { emissions compared to } \\
\text { reinforced concrete construction, tons } \\
\text { Use of renewable energy sources } \\
\text { Sustainability certificates } \\
\text { Awards }\end{array}$ & 1451 \\
& No data \\
No data \\
\hline
\end{tabular}

The amount of waste generated during the construction process was minimal, as all products and structures were brought to the site from the factory. $90 \%$ of the building's structures can be reused or recycled [58]. Local spruce wood was used as the structural material.

The building has a positive impact on the area, with a car park, footpaths, lighting, new trees, shrubs and herbaceous plants. The architectural appearance of the building fits well with its surroundings. For the façade of this building, Canadian cedar planks were chosen, which change color to greyish over time.

Stadthaus (A6) is a nine-storey residential building in London Borough of Hackney. It was the second tallest timber residential structure in the world, after the Forte apartment complex in Australia. The main characteristics of the building are provided in Table 8.

Table 8. Characteristics of the Stadthaus (developed by authors based on [59]).

\begin{tabular}{cc}
\hline Item & Value \\
\hline Year of completion & 2009 \\
Height, meters & 26 \\
Number of storeys & 9 \\
Total area, $\mathrm{m}^{2}$ & 2890 \\
Cost of the project, million EUR & 4.46 \\
Timber structures & Cross-laminated timber panels \\
Quantity of wood used, $\mathrm{m}^{3}$ & 900 \\
Timber certification & PEFC (Programme for the Endorsement of \\
Duration of construction, months & Forest Certification) \\
Energy class & 24 \\
External envelope heat transfer coefficient & No data \\
(U-value, $\mathrm{W} / \mathrm{m}^{2} \mathrm{~K}$ ) & 0.13 \\
Energy consumption, $\mathrm{kWh} / \mathrm{m}^{2}$ per year & 144 \\
Reduction of CO ${ }_{2}$ emissions compared to & 310 \\
reinforced concrete construction, tons & Timber in Construction Awards 2008, Timber \\
Use of renewable energy sources & Journal Awards 2008, British Construction \\
Sustainability certificates & Industry Awards 2009, Building for Life Gold \\
& Standard, CABE 2009 \\
\hline Awards &
\end{tabular}

The façade is designed of 5000 cross-laminated timber panels $(1200 \times 230 \mathrm{~mm}$ each), made of $70 \%$ waste wood. The architects designed the façade of the building in accordance with the changing light and shadows created by the surrounding buildings and trees [59]. The project includes landscaping and children's playgrounds in the inner courtyard. The building has 29 apartments, the local community has its own meeting place in the basement and the first three floors of the building are dedicated to social housing.

The building has two separate staircases and corridors, creating a more welcoming neighborhood for residents. Inside, the timber structures are hidden, but wooden floors dominate the finishes. 


\subsection{Assessment of the Buildings}

Multi-criteria assessment was performed according to the SAW methodology (see Section 3). Table 9 shows the initial decision-making matrix in which the values of the indicators for each building are provided.

Table 9. Decision-making matrix.

\begin{tabular}{|c|c|c|c|c|c|c|c|c|c|c|}
\hline \multirow[t]{2}{*}{ Dimension } & \multirow[t]{2}{*}{ Indicator } & \multirow{2}{*}{$\begin{array}{c}\text { Significance } \\
\text { data }\end{array}$} & \multirow[t]{2}{*}{ Max/Min * } & \multirow[t]{2}{*}{ Unit } & \multicolumn{6}{|c|}{ Buildings } \\
\hline & & & & & A1 & $\mathrm{A} 2$ & A3 & $\mathrm{A} 4$ & A5 & A6 \\
\hline \multirow{11}{*}{ Environmental } & E1 & 0.059 & Max & Tons & 1577 & 2432 & 2000 & 1451 & 1470 & 310 \\
\hline & E2 & 0.047 & Max & Points & 1 & 1 & 3 & 2 & 2 & 2 \\
\hline & E3 & 0.084 & $\operatorname{Max}$ & Points & 2 & 1 & 2 & 3 & 3 & 3 \\
\hline & $\mathrm{E} 4$ & 0.029 & Max & Points & 2 & 1 & 2 & 2 & 1 & 2 \\
\hline & E5 & 0.130 & Min & $\begin{array}{l}\mathrm{kWh} / \mathrm{m}^{2} \\
\text { per year }\end{array}$ & 102 & 135 & 84 & 144 & 65 & 144 \\
\hline & E6 & 0.205 & Max & Points & 3 & 2 & 2 & 1 & 1 & 2 \\
\hline & E7 & 0.062 & Max & Points & 3 & 2 & 2 & 1 & 1 & 1 \\
\hline & E8 & 0.079 & Min & $\mathrm{W} / \mathrm{m}^{2} \mathrm{~K}$ & 0.11 & 0.06 & 0.12 & 0.13 & 0.16 & 0.13 \\
\hline & E9 & 0.057 & Max & $\mathrm{m}^{3} / \mathrm{m}^{2}$ & 0.23 & 0.15 & 0.16 & 0.46 & 0.30 & 0.31 \\
\hline & E10 & 0.082 & Max & Points & 2 & 3 & 2 & 2 & 2 & 2 \\
\hline & E11 & 0.166 & Max & Points & 2 & 3 & 2 & 1 & 1 & 1 \\
\hline \multirow{5}{*}{$\begin{array}{c}\text { Economic/ } \\
\text { Technological }\end{array}$} & ET1 & 0.082 & Max & Meters & 85.4 & 54.0 & 52.8 & 32.2 & 25.0 & 26.0 \\
\hline & ET2 & 0.120 & Max & Number & 18 & 18 & 14 & 9 & 8 & 9 \\
\hline & ET3 & 0.365 & Min & $\mathrm{EUR} / \mathrm{m}^{2}$ & 4527 & 2403 & 3774 & 5195 & 1898 & 1543 \\
\hline & ET4 & 0.147 & Min & $\begin{array}{l}\text { Days per floor } \\
\text { Months }\end{array}$ & 12 & 12 & 15 & 6 & 15 & 7 \\
\hline & ET5 & 0.286 & Min & & 24 & 20 & 20 & 11 & 20 & 24 \\
\hline \multirow{7}{*}{ Social } & S1 & 0.081 & Max & Points & 2 & 2 & 2 & 1 & 3 & 2 \\
\hline & S2 & 0.188 & Max & Points & 2 & 3 & 3 & 3 & 3 & 1 \\
\hline & S3 & 0.196 & Max & Points & 5 & 4 & 5 & 5 & 5 & 2 \\
\hline & S4 & 0.072 & Max & Points & 3 & 3 & 3 & 3 & 3 & 3 \\
\hline & S5 & 0.051 & Max & Points & 3 & 2 & 3 & 3 & 2 & 2 \\
\hline & S6 & 0.291 & Max & Points & 5 & 5 & 4 & 4 & 3 & 3 \\
\hline & S7 & 0.121 & Max & Points & 3 & 3 & 2 & 3 & 1 & 2 \\
\hline
\end{tabular}

Note: * Max-the higher value is preferred; Min—the lower value is preferred.

The initial decision matrix was normalized according to the SAW methodology, the obtained values of the indicators were multiplied by their significances and the obtained vales have been summed to calculate efficiency index $R_{j}$. Finally, rankings of the buildings in each sustainability dimension were determined (see Table 10).

A multi-criteria assessment revealed that the most sustainable building in terms of environmental performance is Mjøstårnet (A1). It received the highest rankings in terms of environmental indicators 'Preserving the natural environment around the building (E4)', 'Renewable energy deployment (E6)', and 'Use of local raw materials (E7)'. This multistorey building is of special landscape significance because of its proximity to Norway's largest lake, and the building, which can be seen from afar, has quickly become an important symbol of the city. The glued laminated timber structures, used for construction of the building, were manufactured at the plant of the Moelven Industrier ASA group, located $15 \mathrm{~km}$ from the construction site, using local spruce forest raw material, which is within a 
radius of $50 \mathrm{~km}$ from the building being built [46]. Wood façade elements were supplied by Woodify AS, about $200 \mathrm{~km}$ from the construction site. From the building's overview terrace, it can be seen where the wood was taken from and where it was processed. The building also has high energy performance (class A in accordance with the Norwegian standard NS 3701), and complies with the requirements for a passive house. In addition, the building is surrounded by electric vehicle charging stations, which use wind energy as an alternative energy source.

Table 10. Normalized-weighted matrix and calculation results.

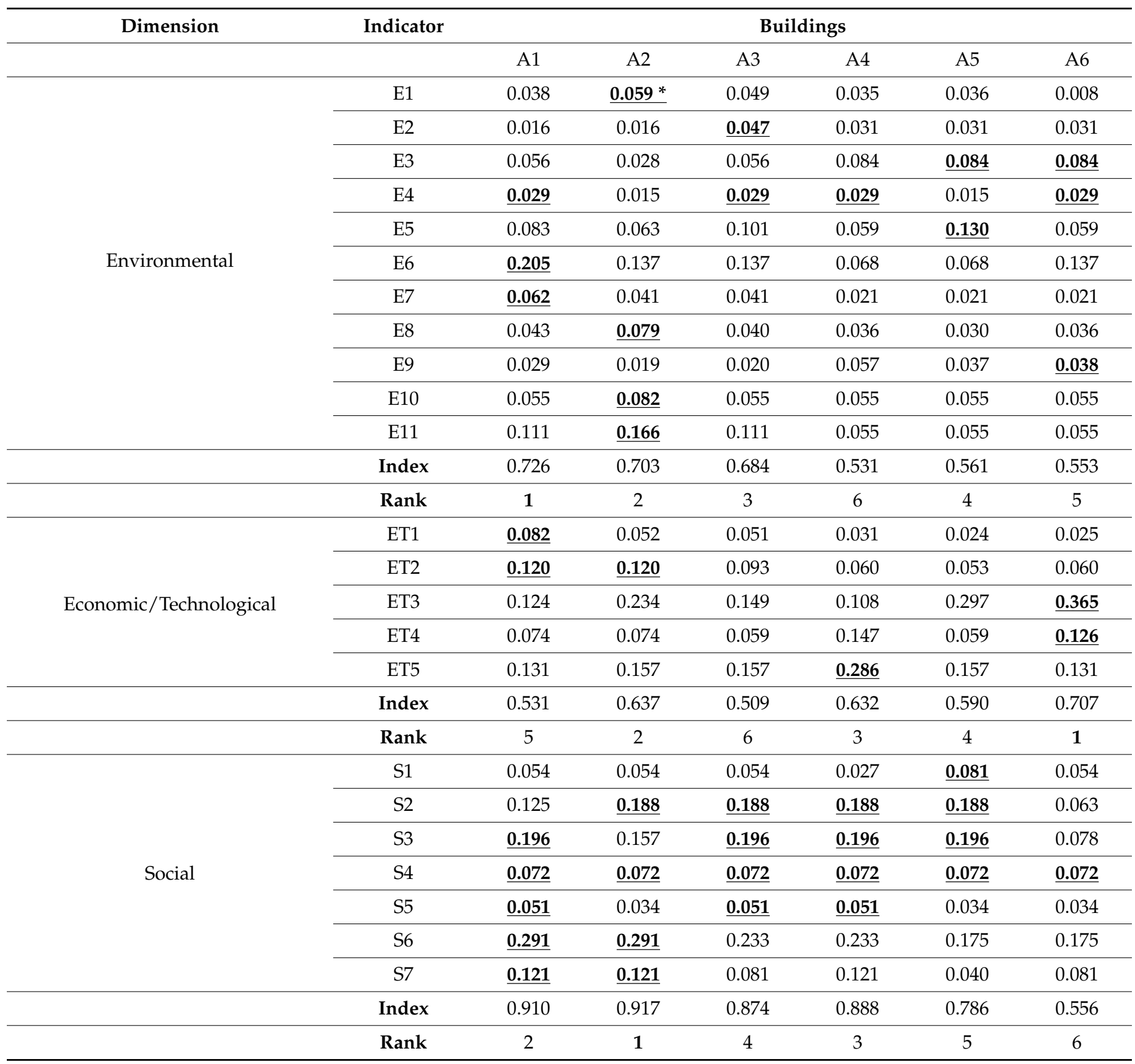

Note: * The highest values are highlighted.

The efficiency index for Brock Commons (A2) is slightly lower compared to Mjøstårnet (A1). It outperformed other buildings in terms of four environmental criteria, wherein reduction of $\mathrm{CO}_{2}$ emissions was the highest, and heat transfer coefficient of the external envelope was the lowest. The building is certified LEED Gold BD + C for new construction. 
The Stadthaus (A6) was ranked as the best building in terms of economic-technological performance, as it had the lowest cost of implementation and installation time of the structures compared to other projects (the installation of the timber structures took 9 weeks, i.e., one floor of the building was installed in an average of 5 business days). However, it was built earlier than other buildings and its height is two times lower compared to Mjøstårnet (A1) and Brock Commons (A2).

In terms of social indicators, the Brock Commons student residence (A2) is the best performing building. It received the highest evaluations against four social criteria: 'Indoor acoustic comfort (S1)', 'Building location, accessibility (S2)', 'Fire resistance (S6)' and 'Spaces for communities (S7)'. The building is designed to meet the 52-54 dB STC (Sound Transmission Class) requirements [47]. The main use of the building is as dormitory rooms for students on campus, so the location on the University of British Columbia site is appropriate, with excellent facilities for students (close to the university, library, and sports fields).

The building is fire resistant. The main load-bearing timber structures are covered with several layers of plasterboard, giving a fire resistance of $120 \mathrm{~min}$ for all structural units [49]. In addition, the entire building is equipped with a fire alarm system and an automatic sprinkler system connected to the municipal water system, with a $2000 \mathrm{~L}$ on-site water tank and a fire pump (both running on emergency power), with the tank supplying water for $30 \mathrm{~min}$ [47]. The building is equipped with student rooms, study and common areas, and lounges. These places become academic and recreational hubs for the student community.

In the next step, an overall sustainability assessment was performed. For this purpose, the aggregated values for each sustainability assessment category were used. Aggregated values were multiplied by the significance of each dimension $(0.333$ each) and the obtained vales were summed to calculate an overall efficiency index.

A summary assessment of the sustainability of buildings is presented in Figure 3.

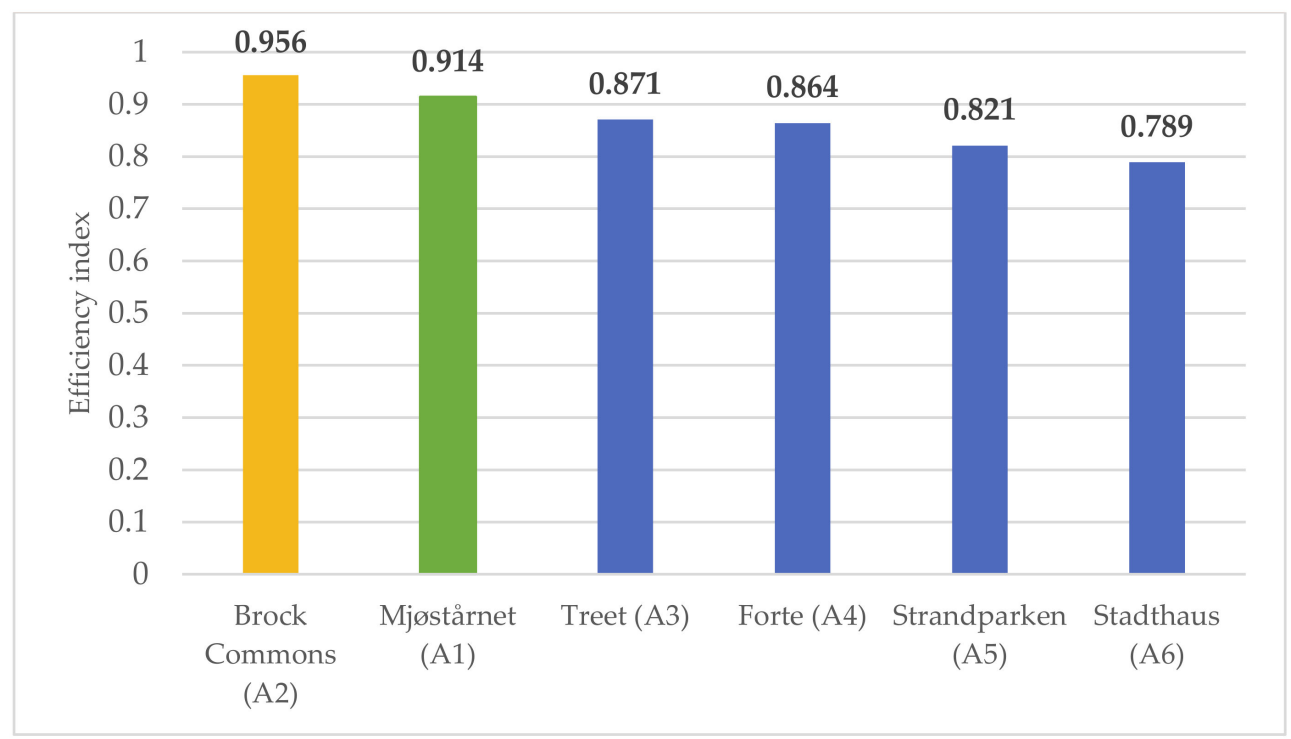

Figure 3. Overall assessment results.

Calculations show that the most sustainable building in all sustainability assessment categories is Brock Commons (A2). This building was in second place in terms of environmental indicators, but the social indicators were better compared to other buildings. The Mjøstårnet building (A1) is in second place, and its overall rating is not much different from that of the Brock Commons building (A2). The building has the highest environmental performance, but the Brock Commons (A2) building has better socio-economic performance. 


\section{Discussion}

Six high-rise timber buildings were selected for the multi-criteria sustainability analysis: Mjøstårnet in Norway, Brock Commons in Canada, Treet in Norway, Forte in Australia, Strandparken in Sweden and Stadthaus in UK. The buildings were compared and assessed based on the original hierarchically structured system of indicators, which covers three sustainability dimensions (environmental, economic/technological, and social) and consists of 23 sustainability indicators. The system of sustainability indicators was adapted to high-rise timber buildings, as none of the existing tools include such a set of indicators. Some timber construction-related indicators, not available in sustainable building rating systems, have been used, e.g., 'reduced $\mathrm{CO}_{2}$ emissions to the atmosphere when comparing a timber-framed building with a similar reinforced concrete building', 'possibility of reusing structures after building demolition', and 'amount of wood used'.

Moreover, many sustainable building rating systems only consider one or two aspects of sustainability. Social and economic indicators are often neglected in the literature [60,61]; according to Berardi [35], the social aspect is the most ignored dimension of sustainability. To fill the gap, the proposed sustainability assessment framework covers all dimensions of sustainability. All dimensions are considered of equal importance and therefore have equal significance.

Research results, based on three dimensions of sustainability, are discussed in more detail below.

According to experts, the most important environmental indicators in the assessment of high-rise timber buildings are renewable energy deployment, energy consumption and sustainability certification (LEED, BREEAM or other). This shows that environmental sustainability cannot be achieved without strong emphasis on energy efficiency and use of renewable sources. This finding is in line with the findings of many studies, e.g., $[5,8,9,23,30]$. LEED, BREEAM or other sustainability certifications are gaining popularity worldwide as it helps to prove that a building is built in a sustainable manner and meets international or global environmental standards. Mjøstårnet was ranked as best in the environmental sustainability dimension because of wind energy deployment, high energy class, planned BREEAM certification and high performance against other environmental indicators.

In the economic/technological dimension, the most significant indicators are the cost of the project, the duration of the project and the duration of the installation of the structure. This corresponds to construction practice; there, efficient management of the budget and time is of the highest importance. In the case of timber construction, duration and cost of the project can be reduced by prefabrication of structures [12]. Stadthaus was ranked as best in the economic/technological dimension because of the lowest cost of implementation and installation time of the structures. However, its height is one of the lowest among other buildings.

Analysis revealed that timber buildings are still economically expensive and only feasible in some countries, although their construction time is shorter and their pollution levels lower than those of buildings made of reinforced concrete structures. The cost of construction is determined by the small number of buildings being built on the market. Additional calculations and studies are needed before a building can be constructed. In addition, usually few companies are involved in the production of timber structures, which increases the cost of construction. Demand for timber buildings is increasing, while supply is still low. It is important to educate investors that timber buildings meet all the technical requirements for a building, to dispel the myths that exist in the market and to convince them to choose to develop timber building projects. As the number of such projects on the market increases, the cost of implementing them shall decrease.

The most important social indicators, in accordance with the experts, are the fire resistance of the building, the indoor microclimate, comfort, the location of the building, and accessibility. Fire safety insurance is one of the major concerns in development of high-rise timber buildings [52]. The indoor microclimate and comfort in high-rise timber buildings are still very little investigated. The location of the building and accessibility of 
public services was emphasized in previous studies, e.g., [14,30,32,34]. Brock Commons was ranked as best in the social sustainability dimension because of high fire resistance, convenient indoor microclimate, comfortable living conditions and good location.

The overall sustainability assessment of the buildings found that Brock Commons in Canada is the most sustainable building, while Mjøstårnet is in the second place with a slightly lower index. These results are in line with the findings of a previous study by Tupenaite et al. [27], where Mjøstårnet was ranked as the best against seven criteria. It can also be observed that the inclusion of additional indicators contributed to holistic assessment of the buildings; thus, rankings changed. Moreover, values of some sustainability indicators may change over time, e.g., a new supermarket or a new kindergarten could be built, thus accessibility of a building may increase. If there are changes in values of indicators, an updated sustainability assessment is required.

This study confirmed the findings of Žegarac Leskovar and Premrov [5], which stated that the age of timber buildings is reflected in their architecture and the height of the buildings increases with the year of construction. In addition, it can be observed that higher buildings, i.e., Brock Commons and Mjøstårnet, received higher sustainability rankings.

Global climate change is making sustainable buildings increasingly popular. In the early 21 st century the number of high-rise timber buildings increased. However, as noted in $[5,52]$, considering sufficient timber resources and the well-developed prefabricated timber building industry, the potential of high-rise timber construction remains partially unexploited. Timber buildings are expected to take an increasing share of the market in the future. It is recommended that companies active in the production, design and construction of timber structures around the world should form a common cluster to create the right legal environment, methodology and technology for the construction and promotion of multi-storey timber buildings in all countries. This will allow companies with no experience to learn from the best practical examples. Newly constructed timber buildings do not have to be taller than existing ones, and the focus should be on increasing the number of such buildings on the market, thus reducing the negative impact of the construction on the natural environment and increasing the potential of circular economy in construction.

\section{Conclusions}

This study aimed to assess the sustainability of modern high-rise timber buildings using multi-criteria assessment methods. For this purpose, an integrated, hierarchically structured system, which covers three sustainability dimensions (environmental, economic/technological, and social) and consists of 23 sustainability indicators, was proposed.

Estimations of the sustainability indicators by the experts revealed that in the dimension of environmental sustainability, renewable energy deployment, energy consumption and sustainability certification (e.g., LEED, BREEAM) are the top priorities. In the economic/technological dimension, the most significant indicator was the cost of the project, followed by the duration of the project and the duration of the installation of the structure. In the social dimension the fire resistance of the building was considered as the most important, followed by the indoor microclimate, comfort, the location of the building, its accessibility. These findings correspond to the findings of other studies.

This case study for six high-rise timber buildings has revealed that none of the buildings is leading in all dimensions of sustainability. However, each building is unique and has its own strengths. The overall assessment of the buildings with the SAW method has revealed that Brock Commons building in Canada has received the highest rank in all dimensions of sustainability. It has also been ranked as the best one in the social sustainability dimension and the second best in the environmental and economic/technological dimensions. The Mjøstårnet building in Norway is in second place, but its overall rating is not much different from that of the Brock Commons building. This building has been ranked as the best one in the environmental sustainability dimension. It can be observed that both buildings have been built recently and are higher compared to other timber buildings. 
It has to be noted that construction of high-rise timber buildings is a little-studied area. In the absence of comprehensive research on timber buildings, it is not possible to promote the development of sustainable timber buildings. This paper analyzed good practices in the construction of timber buildings across various countries. The authors believe that the results could be valuable to building designers, urban planners, investors, construction companies and property developers working to create sustainable environments. The results of the study may also be of international relevance, as it provides an original evaluation framework for a comprehensive assessment of the sustainability of timber buildings.

In the present research, some limitations exist, which should be solved in future studies. First, multi-criteria evaluation of the buildings in six different regions was performed. The influence of the location and different climate zones on sustainability of timber buildings will be studied in future research. Second, a small number of experts have participated in the estimation of significances of indicators. More experts from different specialties could participate in refining the results. Third, the sustainability assessment of high-rise timber buildings was based on the SAW method. In future research, the authors will use other multi-criteria methods to verify the obtained results.

Author Contributions: Conceptualization, L.T., L.K. and T.G.; methodology, L.T.; validation, T.G. and I.G.; formal analysis, I.G.; investigation, V.Z.; data curation, V.Z.; writing-original draft preparation, V.Z. and L.T.; writing-review and editing, L.T.; visualization, L.K.; supervision, L.T.; project administration, L.T.; funding acquisition, L.T. All authors have read and agreed to the published version of the manuscript.

Funding: This research was funded by the European Commission Erasmus+ programme, projects "Knowledge Alliance for Sustainable Mid-Rise and Tall Wooden Buildings" (KnoWood), No. 600903EPP-1-2018-1-DK-EPPKA2-KA, “Circular Economy in Wooden Construction” (Wood in Circle), No. 2020-1-LT01-KA203-077939, “Design and Construction of Environmental High Performance Hybrid Engineered Timber Buildings" (HybridTim), No. 2020-1-DK01-KA203-075045.

Data Availability Statement: All data is available upon request from laura.tupenaite@vilniustech.lt.

Conflicts of Interest: The authors declare no conflict of interest.

\section{References}

1. World Commission on Environment and Development: Our Common Future. 1987. Available online: http://www.un-documents. net/ our-common-future.pdf (accessed on 10 June 2021).

2. Alliance for Buildings and Construction (GlobalABC). 2020 Global Status Report for Buildings and Construction. Available online: https:/ / globalabc.org/news/launched-2020-global-status-report-buildings-and-construction (accessed on 10 June 2021).

3. European Commission. EU Climate Action and the European Green Deal. Available online: https://ec.europa.eu/clima/ policies/eu-climate-action_en (accessed on 5 February 2021).

4. Kuzmanovska, I.; Gasparri, E.; Tapias Monné, D.; Aitchison, M. Tall timber buildings: Emerging trends and typologies. In Proceedings of the 2018 World Conference on Timber Engineering, Seoul, Korea, 20-23 August 2018.

5. Žegarac Leskovar, V.; Premrov, M.A. Review of architectural and structural design typologies of multi-storey timber buildings in Europe. Forests 2021, 12, 757. [CrossRef]

6. Börjesson, P.; Gustavsson, L. Greenhouse gas balances in building construction: Wood versus concrete from life-cycle and forest land-use perspectives. Energy Policy 2000, 28, 575-588. [CrossRef]

7. Oliver, C.D.; Nassar, N.T.; Lippke, B.R.; McCarter, J.B. Carbon, fossil fuel, and biodiversity mitigation with wood and forests. J. Sustain. For. 2014, 33, 248-275. [CrossRef]

8. Skullestad, J.L.; Bohne, R.A.; Lohne, J. High-rise timber buildings as a climate change mitigation measure-A comparative LCA of structural system alternatives. Energy Procedia 2016, 96, 112-123. [CrossRef]

9. Cabral, M.R.; Blanchet, P. A state of the art of the overall energy efficiency of wood buildings-An overview and future possibilities. Materials 2021, 14, 1848. [CrossRef]

10. Zvirgzdins, J.; Plotka, K.; Geipele, S. Circular economy in built environment and real estate industry. In Proceedings of the 13th International Conference “Modern Building Materials, Structures and Techniques, Vilnius, Lithuania, 16-17 May 2019; pp. 704-713. [CrossRef]

11. Taylor, R.H.; Tupenaite, L.; Mills, C.; Agha, A.G. Sustainable construction in wood. In Design, Construction and Management of Wooden Public Buildings; Tupenaite, L., Geipele, I., Eds.; RTU Press: Riga, Latvia, 2021; pp. 31-51. [CrossRef] 
12. Franzini, F.; Toivonen, R.; Toppinen, A. Why not wood? Benefits and barriers of wood as a multistory construction material: Perceptions of municipal civil servants from Finland. Buildings 2018, 8, 159. [CrossRef]

13. Wallenius, M. Wood Construction Reduces Stress and Offers a Healthy Living Environment. 2014. Available online: https: / / www.woodproducts.fi/articles/wood-construction-reduces-stress-and-offers-a-healthy-living-environment (accessed on 11 March 2021).

14. Alwan, Z.; Greenwood, D.; Gledson, B. Rapid LEED evaluation performed with BIM based sustainability analysis on a virtual construction project. Constr. Innov. 2015, 15, 134-150. [CrossRef]

15. BREEAM. Available online: https:/ / www.breeam.com/ (accessed on 10 June 2021).

16. LEED. Available online: https:/ / www.usgbc.org/leed (accessed on 10 June 2021).

17. Perkins, A. Earning LEED Points with Certified Wood. 2019. Available online: https://www.usgbc.org/articles/earning-leedpoints-certified-wood (accessed on 10 June 2021).

18. Wong, J.K.W.; Li, H. Application of the analytic hierarchy process (AHP) in multi-criteria analysis of the selection of intelligent building systems. Build Environ. 2008, 43, 108-125. [CrossRef]

19. Akadiri, P.; Olomolaiye, P. Development of sustainable assessment criteria for building materials selection. Eng. Constr. Archit. Manag. 2012, 19, 666-687. [CrossRef]

20. VillarinhoRosa, L.; Haddad, A.N. Building Sustainability assessment throughout multicriteria decision making. J. Constr. Eng. 2013, 2013, 578671. [CrossRef]

21. Medineckiene, M.; Zavadskas, E.K.; Björk, F.; Turskis, Z. Multi-criteria decision-making system for sustainable building assessment/certification. Arch. Civ. Mech. Eng. 2015, 15, 11-18. [CrossRef]

22. Drejeris, R.; Kavolynas, A. Multi-criteria evaluation of building sustainability behavior. Procedia Soc. Behav. Sci. 2014, 110, 502-511. [CrossRef]

23. Tupenaite, L.; Kaklauskas, A.; Lill, I.; Geipele, I.; Naimaviciene, J.; Kanapeckiene, L.; Kauskale, L. Sustainability assessment of the new residential projects in the Baltic States: A multiple criteria approach. Sustainability 2018, 10, 1387. [CrossRef]

24. Maleki, B.; del Mar Casanovas Rubio, M.; de la Fuente Antequera, A. The multi-criteria assessment of sustainable residential high-rise building design. In Proceedings of the 19th European Roundtable for Sustainable Consumption and Production (ERSCP 2019), Barcelona, Spain, 15-18 October 2019.

25. Dobrovolskienè, N.; Pozniak, A.; Tvaronavičienè, M. Assessment of the sustainability of a real estate project using multi-criteria decision making. Sustainability 2021, 13, 4352. [CrossRef]

26. Nuuter, T.; Lill, I.; Tupenaite, L. Comparison of housing market sustainability in European countries based on multiple criteria assessments. Land Use Policy 2015, 42, 642-651. [CrossRef]

27. Tupenaite, L.; Zilenaite, V.; Kanapeckiene, L.; Sajjadian, S.M.; Gecys, T.; Sakalauskiene, L.; Naimaviciene, J. Multiple criteria assessment of high-rise timber buildings. Eng. Struct. Technol. 2019, 11, 87-94. [CrossRef]

28. Janjua, S.Y.; Sarker, P.K.; Biswas, W.K. A review of residential buildings' sustainability performance using a life cycle assessment approach. J. Sustain. Res. 2019, 1, e190006. [CrossRef]

29. Agol, D.; Latawiec, A.E.; Strassburg, B.B.N. Evaluating impacts of development and conservation projects using sustainability indicators: Opportunities and challenges. Environ. Impact Assess. Rev. 2014, 48, 622. [CrossRef]

30. Tupenaite, L.; Lill, I.; Geipele, I.; Naimaviciene, J. Ranking of sustainability indicators for assessment of the new housing development projects: Case of the Baltic States. Resources 2017, 6, 55. [CrossRef]

31. Calkins, M. Materials for Sustainable Sites; Wiley: Hoboken, NJ, USA, 2009.

32. Hassan, O.A.B. An integrated approach to assessing the sustainability of buildings. J. Eng. Des. Technol. 2016, 14, 835-850. [CrossRef]

33. Yates, K. Sustainable methods for waste minimisation in construction. Constr. Innov. 2013, 13, 281-301. [CrossRef]

34. Li, Q.; Syal, M.; Turner, N.; Arif, M. Constructors and innovation credits in green building projects. Constr. Innov. 2013, 13, 320-338. [CrossRef]

35. Berardi, U. Clarifying the new interpretations of the concept of sustainable building. Sustain. Cities Soc. 2013, 8, 72-78. [CrossRef]

36. Kibert, M. Sustainable Construction: Green Building Design and Delivery; Wiley: Hoboken, NJ, USA, 2008.

37. Saaty, T.L. The Analytic Hierarchy Process: Planning, Priority Setting, Resource Allocation; McGraw-Hill: New York, NY, USA, 1980.

38. Gan, X.; Fernandez, I.C.; Guo, J.; Wilson, M.; Zhao, Y.; Zhou, B.; Wu, J. When to use what: Methods for weighting and aggregating sustainability indicators. Ecol. Indic. 2017, 81, 491-502. [CrossRef]

39. Si, J.; Marjanovic-Halburd, L.; Nasiri, F.; Bell, S. Assessment of building-integrated green technologies: A review and case study on applications of Multi-Criteria Decision Making (MCDM) method. Sustain. Cities Soc. 2016, 27, 106-115. [CrossRef]

40. BPMSG AHP Online System. Available online: http://bpmsg.com/academic/ahp_calc.php (accessed on 5 May 2021).

41. Kendall, M.G. Rank Correlation Methods, 4th ed.; Griffin: London, UK, 1970.

42. MacCrimmon, K.R. Decision Making among Multiple-Attribute Alternatives: A Survey and Consolidated Approach; RAND Memorandum, RM-4823-ARPA; Rand Corp: Santa Monica, CA, USA, 1986.

43. Abrahamsen, R.B. First 14-Storey Wood Building in the World at Bergen in Norway. 5ème Forum International Bois Construction FBC. 2015. Available online: http:/ / www.forum-boisconstruction.com/conferences/20_FBC_15_Abrahamsen.pdf (accessed on 5 March 2021). 
44. Ringsaker. Mjøsparken. Available online: https://ringsaker.custompublish.com/getfile.php/3309697.1897.wrfbscfsyp/Arthur+ Buchardt.pdf (accessed on 5 March 2021).

45. Ostgard, J. Bygg i Massivtre Kommer-RS-Tunet Først Ute. 2017. Available online: https:/ /nyweb.vfk.no/Vestfold-klima-ogenergiforum/aktuelt/bygg-i-massivtre-kommer---rs-tunet-forst-ute/ (accessed on 5 March 2021).

46. Madsen, C.I.L.; Sydow, K.H. Miljøvurdering av Mjøstårnet. Bachelor Thesis, NTNU, Norwegian University of Science and Technology, Trondheim, Norway, 2019.

47. The University of British Columbia. Brock Commons Tallwood House Performance Overview. 2018. Available online: https: //www.naturallywood.com/sites/default/files/documents/resources/brock_commons_cs_-_performance_web.pdf (accessed on 5 March 2021).

48. Korody, N. World's Tallest Wood Building Constructed in Vancouver. 2016. Available online: https://archinect.com/news/ article/149968916/world-s-tallest-wood-building-constructed-in-vancouver (accessed on 5 March 2021).

49. Naturallywood. Introduction to Brock Commons Tallwood House: UBC Tall Wood Building. 2017. Available online: https: / / www.naturallywood.com/emerging-trends/tall-wood/brock-commons-tallwood-house (accessed on 6 March 2021).

50. Gintoff, V. Construction of the World's Tallest Timber Tower is Underway in Vancouver. 2016. Available online: https://www. archdaily.com/787673/construction-of-the-worlds-tallest-timber-tower-is-underway-in-vancouver (accessed on 6 March 2021).

51. Canadian Wood Council. The Advent of Tall Wood Structures in Canada. A Case Study. Brock Commons Tallwood House University of British Columbia, Vancouver Campus. 2016. Available online: https://cwc.ca/wp-content/uploads/2018/07/CSBrockCommon.Study_.23.Ir_.pdf (accessed on 6 March 2021).

52. Hamburg, P.; Lellep, K.; Kiisa, M.; Vahtramäe, E.; Kivil, L.; Jalas, R.; Taylor, R.H.; Šulcienė, V.; Niels, E.H.; Amado, M.; et al. International Study on Best Practices and Knowledge Gaps for Construction of High-rise Timber Buildings, Tallinn, Estonia. 2018. Available online: https:/ / www.hitimber.eu/wp-content/uploads/2021/05/O1.pdf (accessed on 6 March 2021).

53. Abrahamsen, R.B.; Malo, K.A. Structural design and assembly of "Treet"-A 14-storey timber residential building in Norway. In Proceedings of the World Conference on Timber Engineering, Quebec City, QC, Canada, 10-14 August 2014.

54. Kleppe, O.H.; Abrahamsen, R. Construction of Treet-How and Why; International Wood Symposium: Vancouver, BC, Canada, 2016.

55. Lend Lease. Forte-Building Austalias First Timber Highrise. Wood Solutions Presentation, In Proceedings of the Atlanta Conference, 6 February 2013. Available online: https:/ /www.woodworks.org/wp-content/uploads/2013-WSF-ATL-Collins.pdf (accessed on 11 March 2021).

56. Larsson, M.; Erlandsson, M.; Malmqvist, T.; Kellner, J. Climate Impact of Constructing an Apartment Building with Exterior Walls and Frames of Cross-Laminated Timber-The Strandparken Residential Tower; IVL Swedish Environmental Research Institute: Stockholm, Sweden, 2017.

57. Swedish Wood. Strandparken. 2016. Available online: https://www.swedishwood.com/inspired_by_wood/swedish-woodaward/The-Swedish-Wood-Award-2016/The-nominees/strandparken/ (accessed on 11 March 2021).

58. Lundgren, J. The Impact of Life Expectancy in LCA of Concrete and Massive Wood Structures. A Case Study of Strandparken in Sundbyberg. Master's Thesis, Chalmers University of Technology, Göteborg, Sweden, 2014.

59. TRADA. Case Study. Stadthaus 24, Murray Grove, London. Eight Storeys of Apartments Featuring Cross-Laminated Timber Panels. Available online: https:/ / eoinc.weebly.com/uploads/3/0/5/1/3051016/murray_grove_case_study.pdf (accessed on 11 March 2021).

60. Heravi, G.; Fathi, M.; Faeghi, S. Evaluation of sustainability indicators of industrial buildings focused on petrochemical projects. J. Clean. Prod. 2015, 109, 92-107. [CrossRef]

61. Abdul-Rahman, H.; Wang, C.; Wood, L.C.; Ebrahimi, M. Integrating and ranking sustainability criteria for housing. Proc. Inst. Civ. Eng. Eng. Sustain. 2016, 169, 3-30. [CrossRef] 